\title{
The Debate on Constitutional Courts and Their Authority between Legal and Political Constitutionalism
}

\author{
Valerio Fabbrizi, \\ University of Rome - Tor Vergata, IT
}

FABBRIZI, V.: The Debate on Constitutional Courts and Their Authority between Legal and Politican Constitutionalism.

Philosophica Critica, vol. 2, 2016, no. 2, ISSN 1339-8970, pp. 47-69.

The paper is focused on the criticisms that theorists of political constitutionalism raise against legal constitutionalism, especially with regard to the idea of representation and political sovereignty. At the same time, the intention is to reconstruct the debate between legal and political constitutionalism in contemporary liberalism, starting from the so-called counter-majoritarian difficulty. This debate concerns two different approaches: the political one rejects the idea of judicial review by the Supreme Court because it may establish a possible rule of the judges (Michelman; Dworkin). It defends the role of Parliament in constitutional matters, in contrast with the role of the Supreme Court, inasmuch as - according to them - it is not open to political participation. Parliament is considered the only place in which we can exercise our constitutional power and in which our rights could be adequately protected (Bellamy; Waldron; Tushnet; Goldoni). On the other hand, legal constitutionalism upholds the idea of judicial review, defending the role of the Supreme Court as "exemplar of public reason" (Rawls 1993). This article tries to answer to three fundamental questions about constitutional democracy under the banner of political liberalism: 1 . What do we mean by counter-majoritarian difficulty? 2 . What is the answer that legal and political model of constitutionalism give to this question? 3. What is the role of constitutional courts in democratic regimes and what is their authority within the State?

Key words: Political Constitutionalism - Legal Constitutionalism Judicial Review - Supreme Court - Counter-majoritarian difficulty 
In The Least Dangerous Branch, Alexander Bickel discusses one of the central questions of judicial review: the so-called counter-majoritarian difficulty. As he wrote, "when the Supreme Court declares unconstitutional a legislative act or the action of an elected executive, it hinders the will of representatives of the actual people of the here and now; it exercises control, not in behalf of the prevailing majority but against it. That, without mystic overtones, is what actually happens and it is the reason the charge can be made that judicial review is undemocratic" (Ward - Castillo 2005, 124).

\begin{abstract}
"This claim leads scholars to assign great importance to questions of constitutional interpretation, and, consequently, the debate about the counter-majoritarian difficulty has evolved into a quest to identify judicially enforceable principles. According to this view, the Court gains democratic legitimacy and authority by enforceing principles that should supplant those advanced by elected institutions" (Ward - Castillo 2005, 3).
\end{abstract}

According to Bickel, courts - better than legislature or political power - have the power to apply and enforce the Constitution, especially in particularly important moments, against the will of legislative majority. According to some scholars, the Court's decisions about the constitutionality or non-constitutionality of a legislative act or constitutional amendment cannot be reversed by the Parliament or by a legislative majority through an ordinary legislative procedure or judicial review could be considered a "deviant institution in the American democracy" (Ward - Castillo 2005, 124). The Court is regarded countermajoritarian because it requires a special justification for judicial review when the Court decides that a law is unconstitutional, and thus striking it down, it exercises control against majority, not in its representation (Ward - Castillo 2005, 136). So, to present, there are two ways of reasoning. According to the first "empirical" way, the Court - in its decisions - reflects public opinion just like other institutions do. As Kenneth Ward and Cecilia Castillo point out "the Court's decisions are consistent with public opinion nearly two-thirds of the time, making 'majoritarian' a more accurate label for the Court than 'counter-majoritarian'" (Ward - Castillo 2005, 136).

Additionally, the fact that the Court rules against national opinion up to onethird of the time does not mark it as unusual or deviant" (Ward - Castillo 2005, 136). The second reasoning focuses on the idea that the Supreme Court is different from other branches of government or other institutions, because it is not an elective institution. Its members are not elected by people and when they make decisions they do not have to face voters. However, although the Court is different from elected institutions and maybe less democratic, it does not mean that the Court is less legitimate or totally illegitimate. In this sense, "institutional differentiation is a central feature of American democracy. Ironically, the fact that 
the Court is 'deviant' or different from other governing institutions makes it a normal and integral part of American democracy" (Ward - Castillo 2005, 138). A. Bickel insists that judicial review really weakens democratic processes, only because it encourages legislators to shift responsibility of decision-making and governance to courts; in this sense, A. Bickel says, "reduced responsibility invites legislative negligence because legislators have an incentive to acquiesce in unconstitutional demands of their constituents and trust the Court to correct their mistakes" (Ward - Castillo 2005).

Counter-majoritarian difficulty concerns the problem of judicial review, but it seems to undercut elected institutions which promote the sense of common life that animates a legitimate government; Bickel believes that "judicial review must achieve some measure of consonance with democracy" but "he does not believe that it can be made democratic" (Ward - Castillo 2005, 150).

As Richard Bellamy underlines, judicial review is justified as a counter-weight to majorities which want to change constitution for their own particular interests. In this sense, "Courts are said to avoid such problems through being isolated from the electoral process and independent from government interference. Their reasoning is guided by legal norms and standards of natural justice inculcated by the professional training judges receive, and the expectations and conventions of legal and judicial practice and modes of argument" (Bellamy 2013).

One of the most interesting aspects about the counter-majoritarian difficulty is the debate between Ronald Dworkin and Jeremy Waldron. Dworkin defends the idea of the moral lecture of the Constitution and he maintains the authority of the judges as a fundamental element in constitutional democracy. Instead, Waldron insists on the idea that a democracy without judicial review would better work, satisfy and enforce the values that ground our institutions and our conception of justice.

\footnotetext{
"Both Waldron and Dworkin view judicial review in terms of the broader question of how a system of political institutions should make collective decisions. But they disagree about whether we should assess judicial review based on the decisions that we expect judges to make. While Dworkin contends that judicial review is justified if judges' decisions make it more likely that the political community will manifest integrity, Waldron concludes that judicial review offends the value of equality that should animate the political process that resolves disagreements about justice. According to Waldron, it would offend this value no matter how judges decide cases" (Ward - Castillo 2005, 155).
}

In Dworkin's view, judicial review is considered as consistent with democracy, because it increases possibilities for a political community to treat citizens with equal concern and respect. In this sense, judicial review works well if judges reach decisions that promote social and political cooperation and integrity, if their de- 
cisions reflect the political community's principles of justice and help to enforce them.

Waldron defends judicial authority only if it contributes to a broader political process; he remarks that people must develop political institutions to defend political integrity. As we can see, for Waldron, "in a pluralistic society, people not only hold competing conceptions of the good life, they also disagree about justice. Therefore, they must develop procedures that can address the conflicts that arise from these conditions and can do so in a manner that respects the fact of disagreement" (Ward - Castillo 2005). Waldron rejects Dworkin's defence of judicial review and he contends that judges do not have this authority.

According to Waldron, we have a loss of democracy if citizens cannot participate in public and political decisions, even though we talk about democracy. As we read in Ward, in Waldron's opinion, "Dworkin elides the notions of a decision about democracy and a decision made by democratic means. Waldron believes that this elision prevents Dworkin from accounting for the cost to democratic values when a decision about democracy is made through nondemocratic means" (Ward - Castillo 2005, 157). So, we can argue that according to Waldron - when nonelected institutions and nonelected officials make decisions about democratic system, we have a weaker democracy; leaving constitutional power in the hands of the judges means depriving people of its most important power; so representative power becomes useless because citizens cannot exercise it in constitutional matters and democratic values. However, Waldron does not say that judicial review is not consistent with democracy, though he insists that majority rule is the only procedure that resolves controversies about democracy and disagreements about justice, and in order to respect citizens' interest in participating in the discussion this would include allowing disagreement about the meaning of democracy itself.

\section{Legal constitutionalism and the defence of judicial review}

As Marco Goldoni points out, for legal constitutionalism, the relationship between law and morality is fundamental; in this sense, the legitimacy of the law derives mainly from morality and politics is subject to the law. As he writes, outside the limits of legal system, political conflicts would lead to instability and disorder. We need the Constitution to guarantee the necessary conditions to have a democratic politics; Goldoni argues that "the best way to achieve this aim is to conceive the Constitution as a norm which must be applied by the courts. In constitutional rights process, first of all, we remove some fundamental principles from ordinary political discussion and then, we interpret these principles as outside the ordinary political and democratic processes" (Goldoni 2010). 
Political constitutionalists defend - on one hand - the importance of political dimension of constitutionalism and, in this view, the law is subject to politics; on the other hand, the importance of political sphere over the law makes us turn our attention to the so called input reasons, because they allow people to comment on legislative acts and laws that will govern their life (Goldoni 2011). As Goldoni highlighted, political constitutionalism rejects some basic characteristics of legal constitutionalism: for political one, the relationship between citizens and government is not based on contractualist terms - in which court are guardians of constitution - but on direct relationship of trust between people and government. At the same time, there are no questions or issues - even of ethical, religious or moral nature - that can be legitimately excluded from political debate.

Legal constitutionalists suggest four reasons to support judicial review. The first focuses on the idea that constitutional courts deal with individual cases and they are in a better position to decide on individual rights. The second focuses on the reference to a bill of rights as a constraint to the judicial interpretation and as an "aid allowing disputants to focus on the abstract issues at stake" (Goldoni 2012). Following Goldoni, we say that "for political constitutionalists, constrains imposed by legal texts and precedents, given the vagueness inherent to language and the relative case with which courts depart from previous decisions, cannot be deemed to be particularly relevant" (Goldoni 2012, 934). For the third reason, we highlight that judicial decisions come in the form of reason-giving, but - Goldoni argues - this aspect depends on contextual institutional systems and it does not belong only to judicial power. The fourth and last reason is based on the idea that judicial review is essential to legitimization of a democratic institution and it is the only remedy for parliamentarism that protects against the risk of the socalled "tyranny of majority".

"As output-based procedure, judicial review can check the risk of majoritarianism when democracy, aggregating votes, risks sacrificing individuals to collective welfare. Fundamental rights, being 'individual political goals', should not be subordinated to 'notions of the general interest'. The claim is that, from the point of view of political constitutionalists, judicial review of legislation violates the principle of political equality because it decides on issues of general interests as rights and powers without giving to every citizen the possibility to participate and to have a fair say in the process" (Goldoni 2012, 935).

As Bellamy points out, legal constitutionalism takes certain fundamental constitutional principles outside of political sphere, because these principles are considered as constraints and preconditions for a just political system. Legal constitutionalists employ two strategies for depoliticizing principles: the first consists in establishing constraints and boundaries to political sphere, con- 
sidering certain values as beyond politics. The second tries to make an apolitical form of politics in which particular issues are discussed (Bellamy 2007).

The first strategy takes different forms for depoliticizing politics: on one hand, Bellamy argues, it is associated with a liberal tradition expressed - for example by Locke. According to this view, political power exists to protect and ensure certain pre-political rights. As Bellamy writes:

\begin{abstract}
"Politics is limited by such rights in two senses. On the one hand, political bodies and their agents ought not to interfere with individuals in ways that might infringe these rights; on the other hand, they have an obligation to positively promote them. After all, even 'negative' liberty rights, such as the freedom not to be physically assaulted by others, require positive state action in the form of a police force and a regular system of criminal justice in order to be secured" (Bellamy 2007, 147).
\end{abstract}

The second strategy for depoliticizing politics takes an apolitical form of politics to overcome disagreements. Such apolitical strategy appeals to particular modes of public debate to remove the sources of partiality and self-interest, leading to a convergence on public interest (Bellamy 2007). In this case, "if all persons are obliged to argue on a basis of equality with others, so that they can only pursue their own good in ways that show equal concern and respect for the good of everyone else, then it should be possible to arrive at a reasonable consensus on the rules that are to govern their existence and, on some accounts, even collective policies too" (Bellamy 2007, 150).

According to Bellamy, in Rawls the Constitution is conceived both "to prevent democracy from interfering with the private and personal beliefs and activities of individuals" and to defend democracy against these interests, removing the discussion about rights and liberties - and about divisive questions - from the political agenda.

"In Lecture VI of Political Liberalism, Rawls attempts to avoid some of the difficulties of a purely 'ideal' politics by adopting a 'dualist' understanding of the relationship between democracy and the constitution. According to this thesis, constitutional constraints on 'normal' politics result from democratic 'constitutional' politics, most notably at the conventions that bring political regimes into being. He now maintains that the ideal politics of public reason need only operate on these latter sorts of occasions or when they are replicated at times of judicial review by constitutional courts. Since the resulting constraints are themselves the product of popular endorsement, they involve no curtailment of the will of the people. Instead, they represent forms of democratic pre-commitment or selfrestraint not to overturn the basis of democratic politics itself. As such, they are analogous to personal forms of pre-commitment... and like them are presented as an example of self-governance and autonomy, rather than as an abridgement of our collective freedom" (Bellamy 1996, 86). 
Bellamy's critique of legal constitutionalism - specially in Rawlsian theory focuses on the idea that if we cannot distinguish between "constitutional" and "normal" politics, at the same time we cannot portray constitutional judges as "the guardians of the people's own best selves" (Bellamy 1996; Rawls 1993).

In A Matter of Principle, Dworkin asks two important questions about the role of the judges. The first "practical" question is about how judges could decide hard cases: "Do judges in USA or UK make political decisions? Should their decisions be political?" (Dworkin 1985). Dworkin admits that judges make political decisions in one way: in many cases their decisions will be approved by one political group and disliked by others, because these decisions can animate moral, ethical or political disputes and controversies, and because - often - these decisions concern political or legislative acts enacted by the parliament.

"I want to ask whether judges should decide cases on political grounds, so that the
decision is not only the decision that certain political groups would wish, but is
taken on the ground that certain principles on political morality are right. A judge
who decides on political grounds is not deciding on grounds of party politics. He
does not decide in favour of the interpretation sought by the unions because he is
(or was) a member of the Labour party, for example. But the political principles in
which he believes, like, for example, the belief that equality is an important political
aim, may be more characteristic of some political parties than others" (Dworkin
1985, 9).

The second question about the role of judges is not a "practical" question, but rather theoretical: what is the rule of law? The answer is based on the distinction between two different conceptions of the rule of law: Dworkin calls the first "rulebook" conception (Dworkin 1985); it concerns the idea that the power of the state should never be exercised against individual citizens, except according with the rules set out in this common "rule book". The other conception is the so-called "rights" conception, which assumes that citizens have moral rights and reciprocal duties and political rights against the state. According to this conception, moral and political rights have to be recognized and enforced by positive law and through courts and judiciary. As Dworkin argues, "it does not distinguish, as the rule-book conception does, between the rule of law and substantive justice. On the contrary, it requires, as part of the ideal of law, that the rules in the rule-book capture and enforce moral rights" (Dworkin 1985, 12).

Dworkin defends the fact that judges are not elected or re-elected, because the decisions they make are decisions that concerns particular cases and they should be immune from popular control. However, Dworkin notes, it follows that the judges should not make independent decisions about the "rule book" (changing or expanding it) because these decisions should be made only under popular control. In UK, instead, when Parliament - elected by people - is not satisfied with 
a particular decision made by judges, it can override that decision by making a new appropriate legislation (Dworkin 1985). Despite this, Dworkin underlines that legislative power is limited.

"Legislative time is a scarce resource, to be allocated with some sense of political
priorities and it may well be that a judicial decision would be overruled if parlia-
ment had time to pass every law it would like to pass, but will not be overruled
because Parliament does not. In some cases there is a further difficulty in this
answer. When an issue is the subject of great controversy, then Parliament may be
disabled from changing a judicial decision, for practical political reasons, because
any change would infuriate some powerful section of the community or alienate
some parts of a governing coalition" (Dworkin 1985, 18).

Following Dworkin, we can distinguish between two conceptions of democracy. The first is a "majoritarian" conception, in which democracy is based on the idea that all matters of principle should be decided by a majority vote. According to this idea of democracy, an institution like judicial review of legislation, which gives judges the power to overturn acts or decisions approved by a parliamentary majority, is clearly undemocratic (Dworkin 2006).

On the contrary, democracy could be understood as "self-government" of all the people who recognize themselves as free and equal members of the society. Dworkin defends this conception as more democratic than the majoritarian one; on one hand, Dworkin notes that we cannot have real democracy as selfgovernment if citizens don't have the opportunity to play an equal part in political life and it includes equal voting right, equal freedom of expression in public deliberations and so on. On the other hand, we cannot have democracy if people as individuals don't have an equal participation in government (Dworkin 2006).

\footnotetext{
"According to the alternative view of democracy - you might call it partnership democracy - majority rule isn't even legitimate, let alone democratic, unless these conditions are at least substantially met. So if you adopt that partnership view of democracy the argument that judicial review is in its nature inconsistent with democracy fails. I do not mean that constitutional democracy positively demands a structure like ours, a structure that records the democratic conditions in a written, foundational document and assigns final interpretative authority to courts over whether those conditions have been met. You might well think that it would have been better to have given that responsibility to some special elected body, that the decision we either made or ratified in the nineteenth century to give unelected judges that interpretative responsibility was unwise... You can't say that the majority has an automatic, default, title to make those interpretative decisions without begging the question, because of course the majority has no title to govern unless the conditions are satisfied. It begs the question to think that the concept of democracy can dictate which institutions should or should not be given final interpretative authority" (Dworkin 2006, 134).
} 
Frank Michelman asks two questions about constitutionalism and democracy: the first asks how is it theoretically possible to reconcile the ideas of self-determination and popular sovereignty - which are related to democracy - with the limits imposed to the power (related to constitutionalism)? The second question asks how it can be legitimated - and what should be - the role of the constitutional or supreme courts inside these systems?

Michelman answers the first question through what he calls "the paradox of constitutional democracy", that is the difficult reconciliation between two opposed principles such as sovereignty and limitation of the power. As some scholars note, Michelman identifies two "conflicting principles" at the base of institutional systems: "on one hand, the ideal of government subject to law (as constitutionalism) and - on the other hand - the ideal of government through popular will (as democracy)" (Michelman 1999). These principles are opposed because each of them requires different considerations: on one hand, democratic principle requires that the choices about fundamental laws fall within the sphere of democratic decision-making; on the other hand, the principle of constitutionalism requires that at least some of fundamental laws and rights are left out of democratic political decisions (Michelman 1999).

In Michelman's view, the problem of undemocratic nature of unelected constitutional judges would be resolved if citizens could directly interpret the constitution.

\begin{abstract}
"A simple way to do it is to abolish judicial review. If Congress or a state legislature stands charged with enacting laws that the laws of lawmaking prohibit, or with failing to enact laws that the laws of lawmaking command, let the voters decide the charges at the next elections. They can find out how candidates stand on the matter and elect those who will carry out the people's judgment, repealing the offending law or enacting the missing one. Congress then is not the judge of its own cause, or a fox set to guard the people's chickens. Congress may have a cause, but the people are the judge; Congress may be a fox, but the people are the guard. To make the Court the judge and the guard is, from the standpoint of democracy, to put the Court in the people's rightful place. So it might be and has been contended" (Michelman 1999, 21-22).
\end{abstract}

\title{
Political Constitutionalism and the "circumstances of politics"
}

Richard Bellamy - reworking Jeremy Waldron's thesis - gives us the definition of "circumstances of politics" when he says that "circumstances of politics are circumstances where we disagree about both the right and the good, yet nonetheless require a collective decision on these matters. Consequently, the constitution cannot be treated as a basic law or norm" (Bellamy 2007, 5). On one 
hand, according to this view, constitution cannot be considered a fundamental norm, but a question which can be subject of political debate; on the other hand, constitution is identified with political rather than legal system, especially with the ways political power is organized and managed.

"Legal constitutionalists acknowledge that no constitution will survive long unless
citizens can identify with it. Joseph Raz remarks how a constitution must serve 'not
only as the lawyers' law, but as the people's law', its main provisions commanding
general consent as the 'common ideology' that governs public life" (Bellamy 2007,
6).

Other fundamental issue for political constitutionalism is the principle of majority rule, and - as Goldoni writes - it respects equality among citizens in two ways: "on one hand, it recognizes to each opinion an equal importance and the equal opportunity to contribute to the final result of the decision; on the other hand, majority rule devotes equal consideration to the differences, because the decision that it allows to adopt is not influenced by possible results to which the procedure leads us" (Goldoni 2011, 346).

As Marco Goldoni reminds us, in Rawlsian political theory, reasonable disagreement concerns only conceptions of good, but we can reach an overlapping consensus on constitutional essentials and on the conception of justice. Fundamental rights and liberties must be out of ordinary political discussion and the interpretation about principles and fundamental rules is related to the public reason and to Supreme Court, which is its exemplar (Goldoni 2011; Rawls 1993).

"For political constitutionalists, public reason takes plurally procedural character-
ristics and mainly electoral. In a plural and democratic society, it identifies itself -
on institutional level - with parliament and - on procedural level - with electoral
moments. Benefits offered by centrality of parliament are twofold. The first is
probably the most important: parliaments protect rights better than court. Natu-
rally, courts are responsible for respect of individual rights. But the core of political
constitutionalists's argument disputes to courts the ability to deliberate better than
parliaments - on these themes - and with more attention for disadvantaged
people" (Goldoni 2011,349).

Another important aspect is that - for political constitutionalists - parliament has political accountability in front of citizens. It means that government is responsible in front of parliament, which is expression of popular will. Instead, the court - especially the Supreme Court - has no political responsibility. As Goldoni observes, this is not a problem for political constitutionalists when the activity of the courts is focused on interpretation of the laws or on legal disputes. Instead, the problem arises when courts discuss about political issues (like, for example about the principles of a just democratic society). Finally, courts are not 
under popular control because judges are not elected by people (Goldoni 2011). We can argue that "political constitutionalism defends the idea that the only constitution, able to protect rights, enforce the rule of law and the political system, should be found in democratic process itself. So, according to this position, constitution is a political process, not a norm. This process, based on principle of political equality, is both constituent and constituted, according a monist conception of democracy" (Goldoni 2011, 352).

Legal constitutionalism also defends the so called structural entrenchment. For legal interpretation, individual rights precede politics and political process and they are "entrenched" in a constitution or in a bill of rights. Some scholars - like Michelman, for example - propose the conception of unenumerated rights, the idea that there are some important rights outside the disponibility of legislative majorities so that they cannot change or overturn the democratic system (Michelman; Ferrajoli; Ferrara). According to this interpretation “...people can enter the political process insofar they are endowed with certain rights which lie outside the realm of politics. As these rights are recognized as being evident on the basis of reason or as natural rights, their content should not be left to the bargaining that typically characterizes political decision-making" (Goldoni 2012, 931). These rights are protected from political and parliamentary debate in the sense that temporary parliamentary majorities cannot call them into question.

Rights are not left under the exclusive protection of legislation and parliamentary activity, because legislation is "more prone to be guided by utilitarian considerations in decision-making process" (Goldoni 2012). If, for political constitutionalists, rights are not based on an individualistic ground, but on the principle of common good, for legal constitutionalists instead, rights are based on individual interests and they defend them from government. So, as regards political representation and democratic sovereignty, according to political constitutionalists, the best way to ensure the common good and to respect the popular will is to develop a system of equal votes, majority rule and political competition between the parties. According to this discussion, the best way to achieve a political and institutional equilibrium to guarantee the principle of political equality is the so-called neo-parlamentarism (Goldoni 2012; Waldron 1999). As Marco Goldoni notes:

"Parliament is seen by political constitutionalists as the only institution which can express the plurality of opinions and respect disagreements while at the same time reaching an authoritative decision. Waldron has elegantly summed up the authoritative character of the activity of the parliament in the following terms: 'the authority of a law is its emergence, under specified procedures, as a 'unum' out of a plurality of ideas, concerns, and proposals, in circumstances where we recognize a need for one decision made together, not many decisions made by each of us alone'" (Goldoni 2012, 935). 
For legal constitutionalists, there are pre-political features that limit public reasoning; for example, fundamental rights should be considered as pre-political for their nature and because they represent a limit on majority rule. When certain issues are in discussion, we can achieve a sort of general consensus after a proper deliberation and debate (Goldoni 2012).

\begin{abstract}
"Public reason, according to Rawls, is limited to 'constitutional essentials' and matters of basic justice. The conceptual setting for Rawls's construction of public reason is the original position. Through this device, citizens endowed with dual moral power (a sense of justice and a conception of the good) and deprived of the knowledge of their own social and economic status, choose two principles of justice on which two rational agents can apparently reach an agreement. It is easier and more probable that individuals placed in the original position will find 'a shared point of view' in the principles of justice and, since constitutional essentials have to be designed 'to choose the most effective just constitution'. The same principles will constitute guiding output reasons. For Rawls, in a well-ordered polity, citizens legitimately expect their representatives to act and decide according to the idea of public reason. Although Rawls concedes that the Supreme Court is not the only possible seat of public reason, traces of his legalistic understanding of public reason are disseminated throughout his texts. The test Rawls proposes to adopt as a way of checking whether a citizen is acting according to the idea of public reason is quite telling: we should ask 'how would our argument strike us presented in the form of a Supreme Court opinion?"' (Goldoni 2012, 937-938).
\end{abstract}

For political constitutionalists instead, Rawlsian public reason underestimates disagreement because "it already filters some of its more unsettling expressions through an idealized procedure" (Goldoni 2012); as Rawls points out, the idea of rights and fair constitution is supported and defended by the most reasonable political conception of justice, and not by the result of an ordinary political process (Rawls 1993). So, Bellamy's and Waldron's critiques to Rawlsian constitutionalism are focused on the fact that Rawlsian idea of public reason implies the total absence of any reference to political process. In his critique, Bellamy argues that Rawls "depoliticizes" public reason and excludes constitutional essentials from any kind of debate, dispute or contestation. So, "Rawls's public reason is the practice of a reason where conflict is reduced as primarily involving doctrines and overcome by resorting to a device that enables the emergence of consensus" (Goldoni 2012).

Especially in Rawls, the constitutional system is characterized by the idea of effectively depoliticizing fundamental political rights and liberties, not only taking these rights outside the political agenda, but removing from the agenda the most divisive issues and all those values and principles "that might lead us to interpret the political values in conflicting ways" (Bellamy 2007). Bellamy criticizes Rawlsian position arguing that this insulation is impossible and undesir- 
able, because it risks excluding important issues from free and democratic discussion.

\begin{abstract}
"The result, he (Rawls) claims, will be a stable political settlement based on mutual tolerance. By contrast, I shall argue this proposed insulation of the political sphere from people's prime concerns is not only impossible but also undesirable. It prevents politics from performing its crucial function of reconciling differences through negotiation and debate. It also risks excluding important minority issues from the political agenda and thereby delegitimizing the public sphere - the very problem Rawls seeks to avoid. Moreover, it assumes what it purports to show namely, that a functioning democracy requires that citizens adopt a certain view of democratic values" (Bellamy 2007, 102).
\end{abstract}

Bellamy argues that democracy can allow government to possess a legislative majority to make important political decisions, especially when this majority have won the support of a large electoral plurality in free and fair elections. So that, the electoral process amount to a model of public reasoning in which "citizens are shown equal concern and respect as rights holders when deciding on their collective arrangements" (Bellamy 2007).

Bellamy highlights that, in some situations, the claim of governments to be the voice of the people which express a legislative majority are far weaker, so consequently - the need and the legitimacy of an independent institution which works as a check of their power becomes stronger. According to Bellamy's interpretation, there are three arguments that we should follow:

\begin{abstract}
"The first is when executives have to respond to an exceptional crisis that was unanticipated in any party manifesto and where, as in threats to national security, there is an especial risk that civil liberties may be overlooked as a result of precipitate action to meet an emergency. The second is when legislating on matters of private morality that nonetheless have a public dimension: issues such as abortion and gay marriage fit this category, for example. Finally, there are laws and policies involving 'discrete and insular minorities', who may be unable to build electoral coalitions with other groups and hence have no electoral clout whereby their interests might be protected" (Bellamy 2007, 249).
\end{abstract}

Each of these three arguments is pivotal in constitutional and democratic debate. First of all - as regards the first, about exceptional crisis - sometimes it's necessary to make emergency legislation to fight threats such as terrorism. An example is the USA Patriot Act, enacted by President George W. Bush after 9/11 attacks against Twin Towers. As Bellamy underlines, the terroristic threats and the fear of governments to be blamed for failing to adequately protect citizens against terrorism are good reasons for sacrificing liberty to have more "security". So in these cases it is necessary to have a big majority to enact this legislation, but 
in some cases courts may rejects these acts because they may be unconstitutional or undemocratic. In this case, courts would be counter-majoritarian.

Jeremy Waldron has remarked that moral questions, for example, have produced a strong but free and democratic discussion about abortion, As Bellamy notes, "(Waldron) attributes the degree of mutual recognition between prochoice and prolife movement, who were to be found within all parties, to the fact that neither side was being forced to concede they were wrong in their interpretation of matters of fundamental political principle" (Bellamy 2007, 253). In this sense, political process requires recognizing that there are two or more sides of the question at stake and that they deserve to be treated with equality and respect. According to Bellamy, free votes may be extended to different issues (so, also to moral and ethical issues).

\begin{abstract}
"Some republican theorists have argued that free votes ought to be extended to more issues and become the norm for legislative debates on matters of principle. However, the key to the legitimacy of parliament lies in its being both representative and accountable. Parties, as we saw, play a vital role in this regard because they make it possible for views on a range of policies to be brought together in ways that render legislators delegates of the electorate. On the rare occasions legislation relating to personal morality is necessary, then free votes seem appropriate because these issues cut across the dominant party divisions. In this case, the legislature is acting as a rough microcosm of the nation as a whole. But that is not the normal basis on which parliament operates. On most issues of public policy, the agenda has been set at the general election and parliament's role is to reflect voting in that popular arena" (Bellamy 2007, 254-255).
\end{abstract}

Finally, the third argument (about "insular minorities") concerns the fact that, in case of small and concentrated ethnical minorities, it would be possible to devolve special powers to these regions. The problem, Bellamy argues, rises in case of territorially dispersed or isolated groups, that risk to be politically and electorally insignificant and risk not having their interests considered fairly at all. To avoid these risks, "significant minorities can often be important political allies in the formation of coalitions, giving them political influence well beyond their voting strength" (Bellamy 2007). It means that the existence of different cultural or ethnic, or religious minorities - with their needs - is not politically isolated. It is always possible to devote political attention to these minorities, even if - in some case - they seem to be isolated. Bellamy defends the idea of "circumstances of politics" as a tool to enforce democratic system.

Within the circumstances of politics, the commitment to equality of concern and respect that animates most contemporary theories of rights and the rule of law can only be met via a form of self-rule that satisfies the condition of non-domination. A system of equal votes and majority rule complies with this criterion by offering a 
procedural form of public reasoning that provides a fair means for 'hearing the other side'. Competition between political parties further reinforces this system by promoting the responsiveness of political agents to their citizen principals and of citizens to each other (Bellamy 2007, 259).

For Bellamy, judicial review weakens constitutionality of democracy, because it puts a non-political and unrepresentative institution above legislative and democratic institutions. Bellamy's idea is that it doesn't mean the existing democracies are perfect and judicial review is necessarily imperfect. According to Bellamy, "the democratic arrangements found in the world's established working democracies are sufficient to satisfy the requirements of republican non-domination, whereas all efforts to improve on such arrangements through judicial intervention create conditions of domination. Judicial review undermines the equality of concern and respect between citizens that lies at the heart of the constitutional project and that democratic processes serve to secure" (Bellamy 2007, 260). In another passage, Bellamy insists that "the counter-majoritarian and dominating character of judicial review, along with the parallel drawbacks of most forms of becameralism and many neo-federal arrangements, erode yet further the equality of votes and the incentives towards responsibility and accountability of politicians" (Bellamy 2007).

Bellamy also discusses three possible "qualities" of the courts, especially with regard to their democratic character. The first concerns the idea that the courts are not counter-democratic but they uphold democratic constitutional ideals and they can be considered as an exemplary of a true democratic process. In this first argument, Bellamy refers to Rawls and to his idea that US Supreme Court is the "exemplar of public reason" (Bellamy 2013; Rawls 1993); in referring to Rawls, Bellamy argues that Courts could be democratic in three ways:

\footnotetext{
"First, it upholds the principles that are intrinsic to the democratic public sphere. It may override certain decisions of that democratic process but only to preserve democracy. Second, the Court deliberates in an ideally democratic way because it is constrained when it comes to deciding issues that raise 'constitutional essentials' to only employ public reasons - reasons that simply reflect the values of a democratic society and process - when reaching its judgment. Thirdly, the Court has a democratic mandate from the people, as the authorisers of the constitution and the ultimate arbiters of how it should be interpreted" (Bellamy 2013, 338).
}

Following Bruce Ackerman's dualist theory of democracy, Rawls distinguishes "normal" politics from "constitutional" politics. Normal politics is made by parliament and it is democratically legitimated by a political and electoral process, which involves majority rule; at the same time, this "political" stage is subject to a 
higher law (the constitution) that is legitimated and protected by a supermajoritarian and undemocratic court (Bellamy 2013).

Political constitutionalists like Jeremy Waldron and Richard Bellamy criticizes this argument, arguing that it confuses popular sovereignty with democracy (Waldron 1999; Bellamy 2013). This means that We, the People may be sovereign, but it does not mean that the institution they choose would be ipso facto democratic, because they could use their sovereign power to establish a non-democratic regime. Democratic legitimacy implies that the political system be really democratic, not only in its establishment.

The second quality of the courts refers to the idea of "participatory democracy". This argument follows Philip Pettit's distinction between "authorial" and "editorial" - or "contestatory" - democracy. Authorial democracy involves citizens in collective policies, within electoral systems. As Bellamy highlights, "the claim to democratic legitimacy stems from the electoral process being a public mechanism that allows citizens to advance their interests on an equal basis to each other" and the, later, Bellamy adds that "within the context of a given case a Court will hear from all affected parties. In this way, the legal forum comes to reflect the wider political forum" (Bellamy 2013, 345). This implies that legal forum can reflect political forum, although legal reasons for blocking or supporting certain issues are different from political or electoral reasons; in legal case, for example, it will be specific impact of a specific issue discussed by court.
"Above all, the final determination of a case lies not with the litigators but the judiciary. It is their vote alone that counts in Court - indeed, nobody else has a right to vote. Even if the campaigns and hearings themselves were as free and equal as the electoral process, a crucial element is missing - it is not the parties to this process who determine the outcome. Litigation offers the right to petition for rights but is not itself a right to define and determine the rights of the collectivity. Thus, the credentials of litigation as a mode of 'authorial' democracy are weak" (Bellamy 2013, 346).

On the other hand, judges can only decide a case focusing on legislation or on constitution that has itself been democratically endorsed. "These constrains", Bellamy writes, "move litigation towards the model of 'editorial' democracy"' (Bellamy 2013). This case for democratic legitimacy can be related to something like Rawlsian idea of public reason and "it assumes that the editorial rules provided by constitution reflect a democratic consensus as to the norms of a democratic society and that they can be applied in an impartial way that reflects this consensus by the Court" (Bellamy 2013).

"Editorial democracy presumes to offer public criteria that can distinguish groups that are heard within the democratic process but fail to convince from those who 
either fail to get a hearing at all or whose very right to be treated as worthy of a hearing is being denied. As a result, those who litigate in this spirit argue that either the process was deficient or that the decision itself denies them their democratic rights. Yet, we saw how these matters prove impossible to determine without the judiciary taking a position on the very disagreements about political justice that may have been at issue in the legislative process. Thus, an intense minority, who feel very strongly in favour of a policy that the rest of the population feel moderately opposed to, may argue the electoral process has let them down by not appropriately weighting the intensity of their views. However, even if this case is treated as a 'mere' procedural issue it raises contentious and burdensome judgements over process rights" (Bellamy 2013, 347).

The third argument concerns the idea of the "courts as representative democracy" and it is essentially related to the idea of "representation"; it consists of a negative and positive thesis. According to the negative thesis, the democratic critique of the courts fails because, in representative democracies, the legislation cannot be regarded as something that reflects popular will. In this sense, legislation is the result of deliberation of representatives in parliament or legislature; but at the same time, representatives are not delegates or constituent, but they can be considered as trustees (Bellamy 2013).

"As such, a democratic case against judicial review based on the equal right of citizens to participate in legislation proves as telling against the legislature as it does against constitutional Courts. For legislators likewise possess a superior voting weight to ordinary citizens and exercise their independent moral judgment when making decisions concerning the whole of the political community, often going against the express wishes of the citizens who voted for them" (Bellamy 2013, 349).

This argument is focused on a negative thesis, because the distinction between delegate and trustee fails to take into account the full range of representative roles that politicians play in their office. In his article, Bellamy quotes Jan Mansbridge's distinction between "promissory", "anticipatory" and "gyroscopic" conception of representation (Bellamy 2013; Mansbridge 2003). The first conception mainly corresponds to the delegatory model, in which representatives are delegates by electoral body and they has to keep fidelity to their electoral promises. So, "representatives belong to parties and are subject to party discipline, and the findings of the manifesto research group suggest that once elected parties do keep faith to their electoral promises to a remarkable degree promises are often vague policy goals, so representatives may still act as trustees and deliberate over the appropriate means to meet these promised ends" (Bellamy 2007). According to anticipatory conception, representatives could be sensitive to new attitudes or needs among the electorate that follow new political 
circumstances or respond to the success or failure of previous policies. In this sense, representatives are able to anticipate what the voters think and what the voter will approve in the next election (Bellamy 2013). Finally, representatives may have to face unanticipated decisions. As Bellamy argues:

"... In doing so voters may be able to expect they will decide in expected ways
without external incentives because they have been selected on the basis of their
prior beliefs and convictions. Here, representatives fit into the third category and
act as gyroscopes, rotating around a set of relatively stable convictions. Even so,
although their authority derives for the most part from the process of autho-
risation, they are liable to be held accountable should they act other than expected"
(Bellamy 2013, 350).

This means that representatives follows and are sensitive to popular will and voter preferences and they are in dialogue with them, differently from judiciary. Judges can be categorised in gyroscopic and anticipatory argument: gyroscopic argument concerns with the selection of judges, which is directly subject to political control, but - Bellamy argues - even where there's greater independence from political power, courts hope that their decisions gained consensus by the government and the electorate. But, otherwise, "they risk both a loss of legitimacy and an implementation deficit, given there are many ways a judgment can be blocked or undermined through half-hearted, underfunded or delayed compliance. As a result, they practice a weak form of anticipatory representation, so that - as Robert Dahl highlights - 'Courts follow the polls' to the extent of reflecting sustained, national popular opinion" (Bellamy 2013, 350). In the last part of his article, Bellamy highlights that:

"Legislators are only trustees to a limited degree. To the extent judges are, then the degree they can be trusted to uphold democratic values does not rest on the norms embedded in the Constitution or its periodic endorsement by referenda - arguments akin to those of Rawls criticised earlier. Rather, their representativeness stems from a variety of indirect democratic pressures. Once again, the democratic legitimacy of the Court arises from its being within an electoral political system rather than independent from it" (Bellamy 2013, 350).

Jeremy Waldron makes a distinction between democracy and popular sovereignty, in which the principle of popular sovereignty requires that people should have whatever constitution, whatever form of government they want (Waldron 1999), but popular sovereignty does not remove or ignore existing differences among the various forms of government from which people have the possibility to choose. In this sense, he refers to John Locke and Thomas Hobbes, underlining that they argue that the people had the right to vest legislative power in a single individual, in a small group of individuals or in an assembly. For Hobbes, the 
sovereign power could not be vested in a democratic assembly, instead Locke believed in collective body as vested of this power. As Waldron stresses, “... the distinction between a democratic method of constitutional choice and the democratic character of the constitution that is chosen is clearest when we can point to a founding moment in the life of a political society (a moment of constitutional choice) and distinguish between the decision-procedures used at the moment and the decisions-procedures which it was decided to employ in all subsequent political decision-making" (Waldron 1999, 256).

\section{Defending the "rule of judges"}

In this last part of my article, I try to clarify the theoretical framework of discussion, identifying three different lines of reasoning, that represent three main ways of interpreting the counter-majoritarian difficulty and the question of the so-called "rule of judges" in democracy. The first retraces the legal conception of constitutionalism, defending the idea of judicial review and its democratic legitimacy in front of the people (Rawls 1993; Dworkin 1985); the second retraces the political critique to legal version and highlights the position of some important authors that reject the institution of judicial review, defending - on their part the role of the parliament in constitutional decision-making.

For Rawlsian liberal constitutionalism, in a constitutional regime characterized by a strong judicial review, public reason is considered as the reason of Supreme Court. Rawlsian legal constitutionalism is also based on a dualist conception of democracy and it defends a distinction between "supreme" law and "ordinary" law. "Supreme" law is expressed by constituent power and it takes its authority by the people. As Rawls underlines, constitutional power cannot be left to the legislative branch. In Rawlsian conception, Supreme Court protects constitutional essential included in a bill of rights from the legislation of a temporary parliamentary majority or from the interests of a particular political group.

Rawls defends his idea of democratic constitutionalism, highlighting that "if the Court assumes this role and it plays it well, it's wrong to call it sic and simpliciter undemocratic; but it is counter-majoritarian respect to the ordinary law, because, with the power of judicial review, the Court can declare it unconstitutional. The Court is not counter-majoritarian respect to the supreme law, provided that the decision it makes is reasonable in agreement with the constitution, with its amendments and with its interpretations in political mandate" (Rawls 1993, 212).

The role of the Supreme Court in Rawlsian theory is strictly related to the idea of public reason; citizens and legislators, Rawls argues, can vote accordingly with their moral convictions or with their comprehensive views when constitutional 
essentials or matters of fundamental justice are not at stake. When Rawls says that the Court is the exemplar of public reason, he means that the judges cannot refers to their moral values or to their comprehensive doctrines but they must only refer to the constitution and its precedents.

According to Rawls, an amendment is not only a change; it could be necessary to adapt fundamental constitutional values to new political and social conditions or to introduce in constitution a new conception of these values, more inclusive and wider. An amendment could also be necessary to improve the institutions to remove the weaknesses that emerge during the decades.

In political critique of constitutionalism, instead, we can find that important political constitutionalists like Bellamy, Waldron and Tushnet, move their main criticism to legal constitutional view arguing that the counter-majoritarian difficulty is a real problem for democracy, In fact they believe that the so-called "rule of judges" can represent an undemocratic way to solve matters concerning constitutional essentials. In this sense, unelected judges have no popular authority to reject a constitutional amendment or to consider as unconstitutional a legislative act. This critique is obviously based on monist model of democracy in which there is no supreme or constitutional court and in which the protection of constitutional liberties and rights is in the hands of parliament and of legislative majorities, which are expression of popular will and sovereignty. It means that in this position there's also a strong rejection of any form of judicial review of legislation and I consider Mark Tushnet as one of the strongest critics of this institution.

In his most relevant work, Tushnet notes that the question of the scope of judicial review is based on some ideas: on one hand, differently from decisions by unelected judges, decisions by elected legislators have fully democratic legitimacy and justification, and, on the other hand, it implies that legislators have a broader authority to make judgments (Tushent 1999). Tushnet replies to legal constitutionalists' opinions arguing that:

\footnotetext{
"Some defences of judicial review rely on formalist doctrines so that courts can control officials who, the judges believe, are less capable than the judges themselves. That approach makes sense to the judges, but it should not make sense to the officials. A legislator should be able to say, 'Who are they to tell me that I'm no good at my job?' Where the court's constitutional interpretation is shaped by a formalist judgment that legislators are not as good as judges at determining what the Constitution means, a legislator would only reinforce that judgment by thinking that the Constitution itself required the doctrines the judges develop" (Tushnet 1999, 61).
} 
Another critique concerns the fact that, although legal constitutionalists defend judges independence from politics, judicial review in United States is connected to ordinary politics, anyway. So as Tushnet writes, judges are nominated by the president and confirmed by the Senate and they are not chosen by legal experts according to their legal experiences. In that sense, the nomination and confirmation of the judges are deeply political process; it reflects the political direction in the Congress and the political side in the Presidency. So, Tushnet asks, where is this "independence"?

\begin{abstract}
"At times presidents will rely on the judgments of respected lawyers about who the best nominee is, and at times presidents will calculate how nominating one person will appeal to political interest groups. In both cases the president is concerned about how the nomination will affect his or her political standing with important constituencies. At times senators will defer to a president's choices and at times they will vigorously interrogate the nominee. In both cases the senators are concerned about how their behaviour will play with their constituents. At times interest groups will mobilize their constituents around a nomination, and at times they will not. Nomination politics are politics, after all." (Tushnet 1999, 152).
\end{abstract}

\title{
Conclusion. How to respond to these arguments
}

In conclusion of my paper I want to try to propose a third argument about representation in constitutional theory. As we have seen, the problem concerning counter-majoritarian difficulty is a real question that deserves much attention and it still animates a large debate within liberal democratic constitutionalism.

Now, the questions I tried to answer in this paper are three: 1 . What do we mean with counter-majoritarian difficulty? 2. What are the answers the two models of constitutionalism give to this question? 3. Can we propose a third answer that includes the other two?

I tried to answer to the first two questions in the first part of the article, but in this last part I want to try to propose an answer to the third question, in which we can highlight new elements of discussion.

If we follow legal constitutionalism, we have to move from Rawlsian concepttion of public reason and from the related conception of Supreme Court as its perfect exemplar (Rawls 1993). At the same time, we should consider the fact that there are constitutional principles that should be kept outside the political discussion and, consequently, outside the availability of temporary political majorities. In this sense, according to Michelman's idea of unenumerated rights, we cannot put fundamental rights under ordinary political activity and assume that they are subject to what Luigi Ferrajoli and especially Alessandro Ferrara call structural entrenchment. 
Secondly we consider that constitutional judges do not represent an active "political" power and they do not draw their authority from popular vote, but from constitution itself. As Dworkin notes, we cannot consider judges as trustees or representatives of a political party, but we should regard them as guardians of the Constitution and of the principles ensured in it. So it means that when constitutional essentials are at stake, we cannot consider judges as undemocratic, because in these cases the basic principles of the democracy itself are at stake and only judges - independent from politics - can guarantee them.

Our society has to face a new social, cultural and political condition - something that Alessandro Ferrara has designed as hyperpluralism. ${ }^{1}$ - in which we face a new "kind" of society. In this new view of our society, we should have a much broader idea of pluralism: for example, we have to consider that we don't have now only the three "classic" and monotheist religions (Catholic, Jewish, Muslims) but we also have to face new religious movements and faiths; at the same time, questions of new rights arise: gay marriage, abortion etc. Constitutionalism has to face these and new other challenges.

So, Courts are maybe better situated and equipped to recognize and enshrine these new conditions of pluralism; probably the discussion about some new rights cannot be left in the hands of the parliament because probably parliament is too constrained be political reason for which a political groups could boycott the acknowledgement of such rights for moral or ethical reasons. Let's take, for example, the current discussion within Italian Parliament about the so-called "stepchild-adoption" by gay couples. Conservative parties in Italy, according to moral and ethical basis, are trying to boycott the promulgation of this law.

US Supreme Court, in its last Obergefell Sentence has declared gay marriage a constitutional right and it has noted that - in US constitutional system - when constitutional rights and constitutional essentials are at stake, citizens cannot wait for legislative procedures before asserting a fundamental right. In that sense, Supreme Court remarks that "... the right of the individual is not to be injured by the unlawful exercise of governmental power" (Supreme Court 14-556, 2015). This sentence represents one of the most interesting examples of public reason and one of the most recent and important contributions on constitutional theory. The Court remarks that, when individual rights are violated, the Constitution requires redress by the Court, notwithstanding the more general value of democratic decision-making. It entails that the Court is open to individual citizens who come to it to vindicate a fundamental right, even when the majority disagrees or the legislative refuses to act (Supreme Court 14-556, 2015).

1 (Ferrara 2014). 


\section{Bibliography}

BELLAMY R. (1996): Pluralism, Liberal Constitutionalism and Democracy: A Critique of John Rawls's (Meta)political Liberalis. In: Meadowcroft, J. (eds.): The Liberal Political Tradition: Contemporary Reappraisals, Edward Elgar, Cheltenham, 77-100.

BEllamY, R. (2007): Political Constitutionalism. A Republican Defence of the Constitutionality of Democracy, Cambridge University Press, Cambridge.

BELlAMY, R. (2013): The Democratic Qualities of the Courts. A Critical Analysis of Three Arguments. In: Representation, 49, 3, 333-346.

BICKEL, A. (1986): The Least Dangerous Branch: The Supreme Court at the Bar of Politics, Yale University Press, Yale.

DWORKIN R. (1985): A Matter of Principle, Harvard University Press, Cambridge, (Mass.) and London (England).

DWORKIN R. (2006): Justice in Robes, The Belknam Press of Harvard University Press, Cambridge (Mass.).

FERRARA, A. (2014): The Democratic Horizon. Hyperpluralism and the Renewal of Political Liberalism, Cambridge Univerity Press, Cambridge (Mass.).

GOLDONI, M. (2011): Che cos'è il costituzionalismo politico? In: Diritto e questioni pubbliche, 10, 1-22.

GOLDONI, M. (2012): Two Internal Critiques of Political Constitutionalism. In: International Journal of Constitutional Law, 10 (4), 926-949.

MANSBRIDGE, J. (2003): Rethinking Representation. In: The Americal Political Sciences Review, 97, 4, 515-528.

MICHELMAN, F. I. (1999): Brennan and Democracy, Princeton University Press. RAWLS, J. (1993): Political Liberalism, Columbia University Press, New York. TUSHNET, M. (1999): Taking the Constitution Away from the Court, Princeton University Press, Princeton, New Jersey.

WALDRON, J. (1999): Law and Disagreement, Oxford University Press, Oxford. WARD, K. - CASTILLO, C. (eds.) (2005): The Judiciary and American Democracy. Alexander Bickel, the Counter-majoritarian Difficulty and Contemporary Constitutional Theory, State University of New York Press, Albany.

\section{Valerio Fabbrizi}

Departmant of History, Culture and Society

University of Rome - Tor Vergata

Via Columbia

00133 Rome

Italy

valerio.fabbrizi@yahoo.it 